\title{
USTROJSTVO I DJELOKRUG UNUTARNJIH POSLOVA U HRVATSKOJ 1990. - 1992.
}

\author{
$U D K: 351(497.5)$ \\ Primljeno: 15. 02. 2018. \\ Pregledni znanstveni rad
}

\begin{abstract}
Osamostaljivanje Republike Hrvatske zahtijevalo je potrebu formiranja svih dijelova upravnog sustava svojstvenih samostalnoj državi. Zbog izvanrednih okolnosti pobune i ratne agresije, formiranje samostalnog i operativno osposobljenog upravnog resora unutarnjih poslova, bilo je od esencijalne važnosti za održavanje unutarnje sigurnosti. Svrha ovog rada jest istražiti specifičnosti ustroja i djelokruga poslova Ministarstva unutarnjih poslova u razdoblju od početka 1990. do 1992. godine. U tom cilju, daje se prikaz povijesnih događaja političke tranzicije pri čemu je naglasak na onima koji su u bitnome determinirali smjer i dinamiku razvoja resora unutarnjih poslova. Istražit će se i analizirati organizacijski oblici na svim stupnjevima vertikalne diferencijacije kao i djelokrug nadležnosti ustrojstvenih cjelina ministarstva, posebno redarstvenih službi.
\end{abstract}

Ključne riječi: unutarnji poslovi, izvanredno stanje, redarstvene službe

\section{UVOD}

Osamostaljivanje Republike Hrvatske značilo je potrebu formiranja i učvršćivanja svih dijelova upravnog sustava koji su svojstveni samostalnoj državi, a Hrvatska ih je u bivšoj jugoslavenskoj federaciji imala samo u zametku (Pusić, 1997: 201). Kroz proces stjecanja samostalnosti početkom 90-tih godina prošlog stoljeća, otvorena je jedinstvena prilika da se nakon stoljetne nesamostalnosti u provedbi javno-upravnih poslova, izgradi nova moderna hrvatska javna uprava (Koprić, 2011:2). U prvoj fazi razvoja, glavni je zadatak bio stvoriti pravne, organizacijske i druge pretpostavke za formiranje cjelovite državne uprave kao i za nastavak funkcioniranja javnih službi i lokalne samouprave (Koprić, Marčetić, Musa, Đulabić, i Lalić-Novak, 2014: 24). Međutim, proces osamostaljivanja odvijao se u nametnutim okolnostima pobune i ratne agresije. Stoga se kao ključno životno pitanje nametnulo kako se obraniti od agresije i uspostaviti samostalnu i suverenu Republiku Hrvatsku (Smerdel, 2013: 246). U takvim okolnostima i prioritetne potrebe organizacije obrane države, među najvažnijim područjima upravne djelatnosti koji su trebali postati operativno

\footnotetext{
* Sveučilišni specijalist javnog prava i uprave (univ. spec. iur.), predavač na Visokoj policijskoj školi, Ministarstvo unutarnjih poslova, Ravnateljstvo policije, Policijska akademija, Visoka policijska škola, Avenija Gojka Šuška 1, 10000 Zagreb, e-mail: dfranulovic@fkz.hr; dfranulovic@gmail.com.
} 
samostalni, bili su i unutarnji poslovi. Potreba osamostaljivanja državne uprave te nužnost iznalaženja adekvatnih rješenja na sigurnosne ugroze s jedne strane, te politički odnosi unutar federacije s druge strane, determinirali su širinu nadležnosti i djelokrug poslova Ministarstva unutarnjih poslova (dalje u tekstu: MUP). Radi navedenoga, u razdoblju do kraja 1991. godine, pod unutarnjim su poslovima bili objedinjeni poslovi zaštite državne sigurnosti, klasični policijski (redarstveni) poslovi te obrambeno-redarstveni poslovi, s primarnom funkcijom održavanja unutarnje sigurnosti (usp. Tatalović, 2006: 209). I to ne samo kao policijski dio sustava sigurnosti (Savić, 2012), već i kao nadomjestak vojne komponente s obzirom na to da tijekom 1990. i velikim dijelom 1991. godine Hrvatska nije imala ustrojenu vojsku. Formiranje novih organizacijskih jedinica MUP-a predstavlja početak stvaranja samostalnog hrvatskog policijskog sustava i hrvatske vojske. ${ }^{1}$

Svrha je ovoga rada istražiti organizacijske i funkcionalne elemente pravnog uređenja unutarnjih poslova u razdoblju od 1990. do 1992. godine s aspekta zanimanja policijskog upravnog prava. ${ }^{2}$ Nakon uvodnog dijela rada, prikazuje se kratki pregled povijesnih događaja i okolnosti u kojima su se odvijali procesi političke tranzicije Hrvatske pri čemu je glavni naglasak na onim događajima koji su imali neposredni utjecaj na stanje u resoru unutarnjih poslova. Slijedi analiza ustrojstvenih oblika unutarnjih poslova podijeljenih na razdoblje do 1990. i poslije kada se ustrojavaju redarstvene službe 1991. godine. U posljednjem se dijelu rada analizira djelokrug poslova pojedinih ustrojstvenih organizacija.

\section{OPĆI PREGLED STANJA U HRVATSKOJ 1990. - 1992.}

Politička tranzicija koja se događala u bivšoj socijalističkoj Jugoslaviji (dalje u tekstu: SFRJ) krajem osamdesetih i početkom devedesetih godina prošlog stoljeća, bila je pod utjecajem pada „Berlinskog zida“ te lančanog rušenja komunističkih sustava u nizu zemalja (Smerdel, 2013: 246). U hrvatskom je slučaju karakteristična po tome što je vremenski otpočela u jednoj složenoj državi, u miru, a nastavila se u procesu dezintegracije i ratu koji će dovesti do raspada federacije i formiranja samostalnih država. ${ }^{3}$ Volja naroda za uspostavljanje neovisne i suverene države izražena je na prvim slobodnim višestranačkim izborima u travnju i svibnju, kojima je konstituiran Hrvatski sabor 30. svibnja 1990. godine. Međutim, događaj

1 Pojmom policijski sustav „obuhvaćena su sva pitanja koja se tiču položaja policije u društvu, te načina na koji je njena uloga definirana ustavom i zakonima i kako se funkcionalno sve to odražava $u$ praksi“. Pušeljić, Magušić i Nađ, 2008: 77.

Policijsko upravno pravo Staničić definira kao „skup pravnih normi što uređuje organizaciju $i$ ustroj policije kao službe, njeno djelovanje tj. opseg njenih poslova kao i širinu ovlasti kojima raspolaže“. Staničić, 2015: 1. Usp. Borković, 2002: 231, 343-353. Tomašević, 1989., str. 17-54. Ivanda, 1995. Kriterij za određivanje unutarnjih poslova u funkcionalnom smislu jest sadržaj upravne djelatnosti, dok se u definiranju organizacijskih sastavnica polazi od subjekata koji obavljaju unutarnje poslove. Ivanda, 2004: 10. Ovlasti kojima raspolaže policija predstavljaju posebnu tematsku cjelinu i u ovom radu nisu posebno obrađene.

Kasapović (1996: 84) navodi kako je okvir političke transformacije najvećim dijelom bio stanje ,ni rata ni mira " koje je bitno otežavalo donošenje i provedbu strateških političkih odluka. 
koji će u bitnome odrediti buduce stanje u pogledu vojno-policijskih aktivnosti, posebno po pitanju naoružavanja, dogodio se neposredno prije no što će doći do promjene vlasti. Naime, ,Jugoslavenska narodna armija“ (u daljnjem radu: JNA) tijekom svibnja oduzela je oružje Teritorijalne obrane Hrvatske i pohranila ga u svoja skladišta (Borković, 1991: 266). Oduzimanje je provedeno pod izgovorom da je oružje isključivo u nadležnosti vojske, a ne republika, i da postoji mogućnost da se oružje vrati ako republike osiguraju „dobre uslove zaštite“ (Marijan, 2006: 112). No, ispostavit će se da je to bilo samo opravdanje za razoružanje Hrvatske i otimanje oružja koje su kupili i platili građani Hrvatske (usp. Rudolf, 2017: 43., Nobilo, 2000: 21). Sredinom kolovoza, na prostoru sjeverne Dalmacije i kninskog kraja počinje organiziranje naoružanih straža te blokiranje prometnica što poprima obilježja pobune dijela srpske nacionalne manjine protiv nove hrvatske vlasti zbog navodne ugroženosti kao posljedice političkih promjena u Hrvatskoj. ${ }^{4}$ Pobuna se uskoro proširila i na druga područja, pri čemu se JNA svrstala na stranu pobunjenika i onemogućavala provođenje službenih radnji pripadnicima MUP-a (Kosnica, 2011: 157). ${ }^{5}$

Ustav Republike Hrvatske usvojen je 21. prosinca 1990. godine kao izraz narodne volje za uspostavljanje suverene, neovisne, demokratske države, što je potvrđeno na referendumu o suverenosti 19. svibnja 1991. godine (Smerdel, 2013: 267). Na temelju referendumske odluke, Hrvatski je sabor 25. lipnja 1991. godine donio Ustavnu odluku o suverenosti i samostalnosti Republike Hrvatske te Deklaraciju o proglašenju suverene i samostalne Republike Hrvatske, objavljene u Narodnim novinama 31/91. Međutim, posredovanjem misije koju je uputila Komisija Europske zajednice, provedba navedenih odluka je tzv. Brijunskom deklaracijom od 8 . srpnja 1991. godine odgođena na rok od tri mjeseca (Smerdel, 2013: 262). Istekom moratorija, Hrvatski je sabor 8. listopada 1991. godine donio Odluku o raskidu državno-pravnih sveza s ostalim republikama i pokrajinama SFRJ i time konačnu odluku o nezavisnosti Republike Hrvatske. ${ }^{6}$ Ovom je odlukom, u pravnom smislu, okončan proces konstituiranja Republike Hrvatske kao suverene i neovisne države te je preostalo da ona stekne i međunarodni subjektivitet (Čepulo, 2012: 353).

Razdoblje nakon donošenja Ustava Republike Hrvatske obilježeno je eskalacijom pobune i faktičnom ratnom agresijom od višestruko vojno nadmoćnijeg neprijatelja čime je dovedena u opasnost egzistencija Republike Hrvatske i njezinih građana (Bačić, 1997: 55). U takvim okolnostima, 10. rujna 1991. godine donosi se osam uredbi iz područja nadležnosti unutarnjih poslova koje su u svom nazivu imale sintagmu ,u slučaju ratnog stanja ili neposredne ugroženosti neovisnosti $i$ jedinstvenosti Republike Hrvatske ${ }^{\text {“ }} .{ }^{7}$ Time je afirmirano postupanje po pravu nužde, odnosno, afirmirana je mogućnost da se ograniče pojedina ustavom zajamčena

4 Zbog blokiranja prometnica oborenim drvećem, hrvatska strana prozvala je te događaje ,,balvanrevolucijom“. Barić, 2005: 78. usp. Fabijanić Gagro i Vukas, 2008: 1168.

5 O širenju pobune te o uključenosti i o reakcijama na izgrede pripadnika MUP-a v. šire u Runtić, 2003., Nazor, 2011., Kapetanović, 1997., Silber i Little, 1995.

6 Narodne novine 53/1991.

7 Popis svih donesenih uredbi vidi u: Omejec, 1996: 365-369. 
ljudska prava i ljudske slobode. ${ }^{8}$ Dosegom zahvata u ljudska prava najvažnija je bila Uredba o unutarnjim poslovima kojom su bitno proširene ovlasti ovlaštenim osobama (policiji) po pitanju rokova za zadržavanje, kod pretraga, ulaska u tuđi dom, upotrebe vatrenog oružja te ograničavanja kretanja na javnom mjestu (v. šire: Franulović i Tadić, 2011.). Uz dosta kontroverzi po pitanju ustavnosti i ostvarivanja uvjeta za njihovo donošenje, sve su uredbe iz područja unutarnjih poslova stavljene izvan snage 2. travnja 1992. godine. ${ }^{9}$

Od ljeta 1991. godine u traženju modaliteta za rješavanje nastale krize aktivno su bili uključeni i Ujedinjeni narodi. ${ }^{10}$ Vijeće sigurnosti Ujedinjenih naroda na sjednici 25. rujna donijelo je Rezoluciju 713 kojom je uspostavljen potpuni embargo na uvoz oružja. ${ }^{11}$ Za Hrvatsku je zabrana uvoza oružja bila posebno bolna dok je za JNA i za brojne srpske vojne snage koje su raspolagale golemim količinama oružja i streljiva, ovime osigurana zastrašujuća premoć (Gregurić, 1998:306). Imenovan je i posebni izaslanik za Jugoslaviju, američki diplomat Cyrus Vance, sa zadaćom da postavi model za dolazak mirovnih snaga (Jakešević, 2012: 78-91). No, da bi se mirovna misija mogla provesti, bilo je potrebno prethodno uspostaviti primirje. To je učinjeno 2. siječnja 1992. u Sarajevu čime su završile veće vojne akcije te je prestalo daljnje osvajanje hrvatske zemlje. ${ }^{12}$ Republika Hrvatska je 15. siječnja 1992. godine stekla međunarodno priznanje.

Usvajanjem Rezolucije 743 od 21. veljače 1992. godine, uspostavljena je mirovna misija UNPROFOR (United Nations PROtection FORces). ${ }^{13}$ Mirovna misija bila je razmještena na okupiranim područjima Republike Hrvatske. ${ }^{14}$ Prihvaćanjem dolaska međunarodnih mirovnih snaga, hrvatska državna politika željela je zaustaviti ratne sukobe i brže integrirati privremeno okupirana područja (Tatalović, 2006: 107). Zadaće UNPROFOR-a obuhvaćale su demilitarizaciju i demobilizaciju svih oružanih snaga iz područja njihove nadležnosti (Filipović, 2015). Vojni i policijski promatrači trebali su nadzirati djelovanje lokalnih policijskih sastava, te štititi

${ }^{8}$ O uredbama iz nužde kao posebnoj vrsti odredbi koje je ovlašteno donositi izvršno tijelo u slučajevima izvanrednog stanja v. Josipović, 1995., Bačić, 1997., Gardašević, 2010.

9 Uredba o stavljanju izvan snage uredaba iz područja unutarnjih poslova za vrijeme ratnog stanja ili neposredne ugroženosti neovisnosti i jedinstvenosti Republike Hrvatske, Narodne novine br. 19/1992. O ustavnosti uredbi sredinom 1992. godine odlučivao je Ustavni sud Republike Hrvatske tako da je dijelom obustavio postupak, a dijelom odbio prijedlog ocjene ustavnosti pojedinih uredbi iz nužde. Usp. Rješenje Ustavnog suda Republike Hrvatske br. U-I-179/1991 od 24. lipnja 1992. Narodne novine br. 49/1992 i $52 / 1992$.

10 O tome vidi: Rudolf, 1999: 269-279, Barić-Punda, 2001: 339-349, Vukas (ml.), 2002: 645-681.

11 Usp. Rezoluciju 713, https://documents-dds- uy.un.org/doc/RESOLUTION/GEN/NR0/596/49/ IMG/NR059649.pdf?OpenElement (18. ožujka 2016.).

12 Potpisano primirje (,Sarajevsko primirje“) stupilo je na snagu 3. siječnja 1992. godine, a zaraćene strane obvezale su se ostati na tadašnjim položajima.

13 Usp. Rezoluciju 743, http://www.un.org/en/ga/search/view_doc.asp?symbol=S/RES/743(1992) (26. srpnja 2016.).

14 Okupirana područja početkom 1992. zauzimala su površinu od $15.000 \mathrm{~km} 2$, odnosno $26,5 \%$ područja Republike Hrvatske. Šterc i Pokos, 1993: 313. Za razmještaj su bile uspostavljene četiri zaštićene UNPA-zone (United Nations Protected Areas): ,Jug“ (obuhvaćalo je Sjevernu Dalmaciju i Liku), „Sjever“ (Banija i Kordun), „Zapad“ (zapadna Slavonija) i „Istok“ (istočna Slavonija). 
ljudska prava i mirnodopsko stanje javnog reda i mira. Međunarodnim priznanjem te nakon toga razmještajem mirovnih snaga $\mathrm{UN}$-a sastavljenih od vojnih i policijskih snaga, na okupiranim je prostorima osigurana kakva-takva demilitarizacija, razoružanje paravojnih grupa i povlačenje JNA. Kao konačni rezultat političke tranzicije, Arbitražna je komisija Europske zajednice, u Mišljenju br. 11, zaključila da je raspad SFRJ proces dezintegracije koji je trajao određeno vrijeme te da je 4. srpnja 1992. godine završen (Vukas i Fabijanić-Gagro, 2011: 591).

Navedeni pregled pokazuje kompleksnost događaja u razdoblju 1990. - 1992. godine kada su izvanredne okolnosti pobune i faktičkog ratnog stanja u bitnome determinirale smjer i dinamiku svih društvenih kretanja, a posebno prioritete kod formiranja operativno samostalnog sustava državne uprave. Zbog specifičnih političkih okolnosti tranzicijskog razdoblja, Hrvatska je bila limitirana u mogućnostima formiranja vlastitog vojno-policijskog sustava. Potpuno razoružanoj, te naknadno u najkritičnijem razdoblju ratne agresije s uvedenim embargom, jedini mogući oslonac predstavljale su joj policijske snage i skromne vojne snage koje su bile u začetku (Tatalović, 2006: 103). U takvim okolnostima ugroze same opstojnosti države, uspostavio se novi organizacijski sustav, specifičan za razmatrano razdoblje, prema kojemu su obavještajni, vojni i policijski (redarstveni) poslovi ustrojstveno bili pozicionirani u okvirima Ministarstva unutarnjih poslova.

\section{FORMIRANJE I USTROJ UNUTARNJIH POSLOVA I REDARSTVENIH SLUŽBI}

\subsection{Osnovna obilježja unutarnjih poslova u prijelaznom razdoblju 1990.}

U Hrvatskoj je neposredno prije početka procesa demokratske tranzicije prevladavao decentralizirani ustroj i upravljanje unutarnjim poslovima. ${ }^{15}$ Shodno decentraliziranim ovlastima, svaka je općina imala svoj općinski (gradski) sekretarijat za unutrašnje poslove (dalje u tekstu: SUP), te autonomno odlučivala o njegovu ustroju, financiranju i imenovanju rukovoditelja (v. šire, Zmijarević, 2007.). Suštinske promjene događaju se 1. siječnja 1990. godine stupanjem na snagu Zakona o unutrašnjim poslovima. ${ }^{16}$ Sustav s decentraliziranim elementima organizacije i upravljanja u potpunosti se mijenja i centralizira prema republičkom

15 Normativne osnove decentraliziranog sustava bile su sadržane u Ustavu SR Hrvatske iz 1974. godine, Narodne novine br. 8/1974., u Zakonu o organima unutrašnjih poslova, Narodne novine br. 11/1977. (do prestanka važenja 1. siječnja 1990., ovaj je zakon pet puna mijenjan i dopunjavan: Narodne novine br. 34/1979, izmjene i dopune, 44/1979 - pročišćeni tekst, 27/1981. - izmjena, 12/1985. - izmjena i dopuna, 23/1985. - pročišćeni tekst, 46/1987. - izmjene, 55/1988. - izmjene), te u Zakonu o organizaciji i djelokrugu republičkih organa uprave i republičkih organizacija, Narodne novine br. 44/1979, izmjene i dopune 18/1982, 33/1983, 29/1985, 17/1986, 19/1989, 31/1990. Zakon je prestao važiti stupanjem na snagu Zakona o ustrojstvu republičke uprave od 8. listopada 1990., Narodne novine br. 41/1990.

16 Narodne novine br. 55/1989. 
SUP-u. Dotadašnji gradski SUP-ovi i SUP-ovi zajednica općina postaju sekretarijati za unutarnje poslove u čijem su se sastavu nalazile stanice javne sigurnosti (raniji općinski SUP-ovi). ${ }^{17}$ Umjesto stotinjak općinskih i dva gradska SUP-a, ustanovljeno je 17 većih SUP-ova. ${ }^{18}$ Nekretnine, pokretne stvari i druga sredstva dotadašnjih općinskih i gradskih SUP-ova preneseni su na korištenje bez naknade republičkom SUP-u. Navedenim promjenama uspostavljen je hijerarhijski sustav odlučivanja i imenovanja rukovoditelja, $u$ potpunosti pod kontrolom republičkog tijela državne uprave. Uveden je dodatni ustrojstveni oblik unutar sustava koji do tada nije postojao u vidu 17 većih SUP-ova. U odnosu na dotadašnji decentralizirani sustav odlučivanja, koji je bio fragmentiran na više od stotinjak lokalnih jedinica, novim se rješenjima svakako poboljšao sustav upravljanja i koordinacije. ${ }^{19}$ Onemogućavanje lokalne sredine da bira rukovoditelje koji su prije svega bili „politički podobni“, ali u profesionalnom smislu uglavnom diletanti, za cilj je imalo profesionalizaciju sustava. ${ }^{20}$ Međutim, utjecaj politike na kadrovska rješenja, čak i u slučaju kada su oni bili strukovni profesionalci, time nije prestao, već se „,samo“ premjestio na nove, više hijerarhijske razine odlučivanja. Ipak, imajući u vidu sve kasnije događaje, smatramo da su centralizacija i uvođenje hijerarhijskog sustava upravljanja imali pozitivan učinak. No, time je ujedno počeo proces povećavanja broja ustrojstvenih teritorijalnih jedinica što će se u narednom razdoblju radi potrebe formiranja samostalnih tijela unutarnjih poslova, i posebno nužnosti suočavanja s rastućom agresijom, odnosno obranom države, nastaviti.

\subsection{Formiranje novih ustrojstvenih jedinica i povećanje broja operativnih pripadnika unutarnjih poslova}

Nakon političkih promjena sredinom 1990. godine, pojavilo se pitanje dostatnosti operativnih djelatnika unutarnjih poslova za ispunjavanje svih obveza buduće samostalne države (Nazor, 2011: 18). U cilju povećanja broja neposrednih izvršitelja, na Policijskoj akademiji u Zagrebu 5. kolovoza 1990. godine pokreće se

17 V. Odluku o sjedištu i području na kojem se osnivaju sekretarijati za unutrašnje poslove, klasa: 200-01/89-01/11. I ur. br. 5030107-89-4400, od 25. prosinca 1989. Cit. prema Zmijarević, 2007: 285.

18 Novom organizacijom sekretarijati i stanice javne sigurnosti svrstani su u četiri kategorije, a stanice milicije u sjedištu sekretarijata svrstane su u tri kategorije. Kategorizacija SUP-ova: I. kategorija: Zagreb; II. kategorija: Osijek, Rijeka, Split; III. kategorija: Bjelovar, Dubrovnik, Karlovac, Pula, Sisak, Slavonski Brod, Šibenik, Varaždin, Vinkovci, Zadar; IV. kategorija: Gospić, Kutina, Zabok (ukupno 17). Stanica javne sigurnosti bilo je ukupno 89. Usp. Zmijarević, 2007:286 i Pravilnik o izmjenama i dopunama Pravilnika o unutrašnjoj organizaciji i načinu rada RSUP-a SR Hrvatske, Kab. SP br.4/1-1990. od 29. siječnja 1990.

19 U kontekstu pregleda razvoja lokalne samouprave u razdoblju prije samostalnosti Hrvatske, Koprić (2006:176) ističe da je ,lokalna autonomija bila tako izražena da su neke od važnih državnih službi (policija, porezna služba, $i$ druge) patile od izrazitog nedostatka efikasne koordinacije $i$ jedinstvenog vođenja".

20 Kako navodi Pusić (2002: 34), profesionalni službenik radi za plaću, koja je temelj njegove materijalne egzistencije, poslu u upravi posvećuje pretežni dio svog radnog vremena, i za taj se posao posebno obrazuje. Profesionalizacija i depolitizacija državne uprave prije svega znače promicanje struke na račun političkog diletantizma, Marčetić, 2006: 125. 
tečaj „Prvi hrvatski redarstvenik“. ${ }^{21}$ Tečaj je predstavljao prvu hrvatsku obrambenu (dragovoljačku) postrojbu. Potom je 7. rujna 1990. godine ustrojena Antiteroristička jedinica Lučko kao prva oružana formacija tadašnje novoosnovane hrvatske vlade. U svrhu zaštite nacionalnog suvereniteta i teritorijalnog integriteta, 28. studenog 1990. godine, Vlada donosi Odluku o načelima organizacije i ukupnom brojčanom sastavu policije u Republici Hrvatskoj u slučaju rata, neposredne ratne opasnosti i u drugim izvanrednim prilikama br. 1072/90, koja nije bila objavljena u Narodnim novinama. Temeljem ove odluke započelo se s jačanjem policijskih (redarstvenih) snaga kao jedine zakonske mogućnosti naoružavanja za slučaj izbijanja rata (Manolić, 2015:180). Neposredan rezultat navedenih aktivnosti bilo je osnivanje 18 posebnih postrojbi policije od kojih je svaka policijska uprava imala jednu postrojbu, dok je jedna bila u nadležnosti MUP-a. Ovime je bitno povećan i broj angažiranih pripadnika MUP-a, sa 6800 ljudi sredinom 1990. na oko 18.500 osoba krajem siječnja 1991. godine (Marijan, 2006: 98). ${ }^{22}$

\subsection{Ustrojavanje redarstvenih službi 1991.}

U travnju 1991. godine, za obavljanje unutarnjih poslova u MUP-u su ustrojene nove organizacijske cjeline nazvane redarstvene službe: ${ }^{23}$ Služba za zaštitu ustavnog poretka (dalje u tekstu: SZUP), Služba javne sigurnosti, odnosno Policija i Zbor narodne garde (dalje u tekstu: ZNG). ${ }^{24}$ Izmijenjeni su i službeni nazivi za

${ }^{21}$ Tečaj se sastojao od 1689 pripadnika postrojenih u dvije bojne, svaka podijeljena u 8 satnija. Nazor, 2011: 75 .

22 O dinamici i osnovnim obilježjima razvoja javne uprave, uključujući i osvrt na broj službenika u pojedinim resorima, v. šire Koprić, 2006: 348-350.

23 Pojmovno, redarstvene službe vežu se s izrazima „redar“ (arh. razg. općinski policijski službenik; redarstvenik), „redarstvenik“ (onaj koji služi u redarstvu; policajac), „redarstvo“ (pov. gradska policija, arh. policija). Usp. Anić, 1994: 885. Navedeni izrazi su dio hrvatskog tradicionalnog nazivlja koje se koristilo u sustavu unutarnje sigurnosti poslova još od srednjeg vijeka. Radi sigurnosne dimenzije koju je redarstvo imalo po pitanjima sigurnosti zemlje i regulacije određenih odnosa među ljudima, u određenim se razdobljima koristio i naziv ,redarstvo sigurnosti“", (usp. Žigrović-Pretočki, 1917: 58-60, prema Koprić, 2015: 2). Početkom 20. stoljeća Walka „redarstvo“ definira kao: „samostalnu granu unutarnje uprave kojoj je zadaća skrbiti za sigurnost državnu, javnu i opću, mjesnu te pojedinca, predusrećući, pronalazéci, izvidjajući, ustanovljujući te privadjajući kazni i reparirajući narušaje u tom svom djelokrugu". V. Walka, 1923: 9. Za vrijeme Banovine Hrvatske 1939. - 1941. banska je vlast bila podijeljena na 11 odjela. Jedan od odjela bio je Odjel za unutarnje poslove koji se dalje dijelio na 6 odsjeka među kojima i Redarstveni odsjek, nadležan za čuvanje javnog reda i mira, zaštitu osobne i imovne sigurnosti, suzbijanje kriminaliteta, žandarmeriju, gradske policije, suzbijanje prostitucije, uređenje prometa, pregled motornih vozila, međunarodnu suradnju, profesionalno i dobrovoljno vatrogastvo, izdavanje isprava $\mathrm{i}$ viza, obavještajnu službu, nadzor nad strancima, tisak i cenzuru, evidenciju osoba, nadzor nad lokalima i slično. O organizaciji i djelatnostima redarstva na prostoru Hrvatske kroz povijest, v. Beuc, 1985. Mikulan, 2003., usp. i Koprić, 2015., 10-14. U studenome 1990. godine, mijenjaju se nazivi „unutarnji poslovi“, umjesto „unutrašnji poslovi“, „,policijske uprave“ umjesto „,sekretarijata za unutrašnje poslove“ i ,policijske stanice“ umjesto „stanice javne sigurnosti“. Usp. Zakon o izmjenama zakona o unutrašnjim poslovima, Narodne novine br. 47/1990.

24 Redarstvene službe osnovane su temeljem Zakona o izmjenama i dopunama Zakona o unutarnjim poslovima što je usvojen u Hrvatskom Saboru 18. travnja 1991. godine, objavljen u Narodnim novinama br. 19/1991. Pročišćeni tekst objavljen je 27. svibnja 1991. u Narodnim novinama br. 29/1991. Dalje u tekstu citiramo pročišćeni tekst i koristimo naziv Zakon o unutarnjim poslovima. 
neposredne izvršitelje. Tako su riječi „pripadnici milicije“ zamijenjeni riječima „pripadnik Policije i Zbora narodne garde“, odnosno ,ovlaštene službene osobe“. ${ }^{25}$ Ovim je promjenama dokinut ideološki utemeljen naziv „milicija“ za uniformirane pripadnike unutarnjih poslova koji dobivaju u međunarodnim okvirima uobičajeni i svakome prepoznatljiv naziv policija. Izdvajanjem ZNG-a iz MUP-a krajem 1991. godine, pojam redarstvene službe ograničava se na SZUP i Policiju, dok se za neposredne izvršitelje koriste nazivi pripadnici (određene) redarstvene službe. ${ }^{26}$

\subsubsection{Ustroj i organizacija SZUP-a}

Novoustrojena redarstvena služba SZUP-a nastavila je s radom prema dotadašnjoj organizacijskoj strukturi koja se sastojala od sjedišta u Zagrebu, te deset regionalnih centara (u Bjelovaru, Gospiću, Karlovcu, Osijeku, Puli, Rijeci, Sisku, Splitu, Varaždinu i Zagrebu). ${ }^{27}$ SZUP je bio centraliziran sa sjedištem u Zagrebu s mogućnošću da se za obavljanje poslova iz njegove nadležnosti na određenim područjima osnivaju organizacijske jedinice službe. Sjedište i područja na kojima su djelovale organizacijske jedinice SZUP-a određivala je Vlada Republike Hrvatske na prijedlog ministra unutarnjih poslova. ${ }^{28}$ Redarstvena služba SZUP-a će u kasnijem razdoblju činiti jezgru obavještajne zajednice zajedno s ostale tri službe: Hrvatskom izvještajnom službom, Sigurnosno-informativnom službom Ministarstva obrane i Obavještajnom upravom Glavnog stožera Oružanih snaga. ${ }^{29}$

25 U obrazloženju Zakona o unutarnjim poslovima, iznosi se objašnjenje kako je dotadašnja služba državne sigurnosti preimenovana u službu za zaštitu ustavnog poretka čime se preciznije određuju zadaci i poslovi te službe, a naziv službe usklađuje se s postojećim nazivima sličnih službi u zapadnoeuropskim zemljama. Također, da se iz istih razloga za poslove Službe javne sigurnosti utvrđuje jedinstveni naziv „policija“. Usp. Zakon o unutarnjim poslovima, 1992., str. 12.

26 Usp. Čl. 30.-32. Zakona o unutarnjim poslovima. Ovdje treba upozoriti da Ustav Republike Hrvatske, Narodne novine 56/1990 u više odredbi (24., 34., 59. i 60.) koristi pojmove „redarstvo“ i „redarstvene vlasti. Tako u članku 24., „,... redarstvene vlasti mogu i bez sudskog naloga ili privole držatelja stana ući u dom ili prostorije te izvršiti pretragu bez nazočnosti svjedoka...", u članku 34. ,... bez sudbenoga naloga redarstvo može, uz obvezu da je odmah preda sudu, uhititi osobu protiv koje postoji osnovana sumnja da je počinila teško kazneno djelo određeno zakonom “. S obzirom na tadašnju strukturu organizacije MUP-a i nepostojanja hrvatske vojske, očito je da su se pojmom „redarstvo“ podrazumijevale sve službe ustrojene u MUP, dok su se pojmom „redarstvene službe“ podrazumijevali osnovni ustrojstveni oblici (SZUP, Policija i ZNG). Redarstvene službe policije, kao ustrojstvene cjeline prestale su postojati stupanjem na snagu Zakona o policiji 1. siječnja 2001. godine, Narodne novine 129/00, i formiranjem jedinstvene službe Policije. Redarstvena služba SZUP-a prestala je s radom stupanjem na snagu Zakona o sigurnosnim službama Republike Hrvatske 1. travnja 2002. godine, Narodne novine 30/2002. Time ujedno prestaje i operativno korištenje naziva redarstvene službe.

27 Usp. Čl. 11. Zakona o unutarnjim poslovima.

28 Čl. 13. Zakona o unutarnjim poslovima.

29 O sigurnosnim (obavještajnim) službama i njihovim ulogama u sustavu nacionalne sigurnosti v. šire u Tatalović, 2006: 217-227. 


\subsubsection{Organizacija Policije}

Za obavljanje poslova redarstvene službe policije, novim zakonskim rješenjima u bitnome je povećan broj organizacijskih jedinica, hijerarhijski raspoređenih u četiri stupnja. Pored sjedišta MUP-a, osnovane su organizacijske jedinice policijske uprave. Teritorijalni ustroj policijskih uprava i pripadajućih policijskih postaja odredila je Vlada Republike Hrvatske 19. lipnja 1991. donošenjem Uredbe o sjedištu i području na kojem se osnivaju policijske uprave. ${ }^{30}$ Prema navedenoj uredbi, utvrđene su policijske uprave: Bjelovar, Dubrovnik, Gospić, Karlovac, Kutina, Osijek, Pula, Rijeka, Sisak, Slavonski Brod, Split, Šibenik, Varaždin, Vinkovci, Vukovar, Zabok, Zadar i Zagreb, kao i osnivanje 102 policijske postaje. ${ }^{31}$ Osim policijskih uprava i policijskih postaja, prema odluci ministra od 25. travnja 1991. godine, započelo je s radom 111 novih policijskih ispostava kao najnižeg ustrojstvenog oblika policijske organizacije (Zmijarević, 2007: 331). Pored navedenih teritorijalnih organizacijskih jedinica, ministar MUP-a bio je ovlašten osnivati posebne jedinice radi posebnih razloga sigurnosti, održavanja ili uspostavljanja javnog reda i mira, kao i u slučaju opće opasnosti prouzročene elementarnim nepogodama i epidemijama. ${ }^{32}$

\subsubsection{Ustroj ZNG-a}

ZNG je osnovan Odlukom o ustrojstvu Zbora narodne garde 20. travnja 1991. godine (odluka nije bila javno objavljena). ${ }^{33} \mathrm{ZNG}$ se definirao kao ,profesionalna, uniformirana, oružana formacija, vojnog ustroja za obrambeno-redarstvene dužnosti" (čl. 26. st. 1. Zakona o unutarnjim poslovima). No, ono što je upućivalo na stvarnu, vojno-obrambenu narav ove službe jest činjenica da je jedinicama ZNG-a zapovijedalo Ministarstvo obrane. ${ }^{34}$ Teritorijalna nadležnost ZNG-a prostirala se na cjelokupnom teritoriju Republike Hrvatske. Ustroj ibroj pripadnika ZNG-a utvrđivao je Predsjednik Republike na prijedlog ministra obrane i ministra unutarnjih poslova. Bilo je planirano formiranje četiri djelatne brigade sa sjedištem u Zagrebu, Sisku,

30 Uredba Vlade RH od 19. lipnja 1991., klasa 200-01/91-02/05 i ur. br.5030115-91-2, Narodne novine 30/1991.

31 Uredbom o dopuni Uredbe o sjedištu i području na kojem se osnivaju policijske uprave, Narodne novine 44/91, dodana je alineja 19. kojom se osniva i Policijska uprava Županja za područje općine Županja. Na promjene ustroja tijekom 1991. godine djelovale su i ratne prilike. Tako je, zbog okupacije, sjedište PU vukovarske bilo u Vinkovcima, odnosno zbog posebnog statusa kotareva Glina i Knin, na njihovim je područjima bilo predviđeno formiranje policijskih uprava koje nisu bile operativne (usp. Koprić, 2010: 666).

32 Čl. 24. Zakona o unutarnjim poslovima.

33 Na pitanje odakle potječe naziv ZNG, Špegelj (2001: 213) navodi kako je početna ideja bila da se te ,jedinice zovu Civilnom gardom, po uzoru na SAD, da bi se onda radno vodile kao Narodna garda, dok potkraj travnja predsjednik Tuđman nije zapovjedio da se prozovu Zborom narodne garde, te da se ustroji šest brigada".

34 Usp. čl. 27. Zakona o unutarnjim poslovima. Za prvog zapovjednika ZNG-a imenovan je 21. lipnja 1991. godine general-pukovnik Martin Spegelj. V. Odluku o imenovanju zapovjednika ZNG-a, Narodne novine br. 30/1991. 
Osijeku i Splitu, kao i pričuvnih brigada i samostalnih bataljuna..$^{35}$ Ustrojavanje novih organizacijskih jedinica ZNG-a intenzivno je nastavljeno tijekom ljeta. Do 12. kolovoza ustrojene su četiri brigade pri čemu je oko 2000 policajaca prešlo u ZNG, najviše u Zagrebu za potrebe 1. i 2. brigade, te nešto manji broj za potrebe 3 . (osječke) i 4. (splitske) brigade (Špegelj, 2001: 213). Do sredine rujna 1991. godine osnovano je Zapovjedništvo s podstožernim postrojbama i ustanovama djelatnih brigada, jednog bataljuna ZNG-a te pričuvnih brigada i bataljuna (Marijan, 2006: 99). Osnivanje redarstvene službe ZNG-a predstavljalo je prvi korak institucionalnog ustrojavanja hrvatske vojske. U drugoj polovici 1991. godine, ZNG je izdvojen iz MUP-a i stavljen u nadležnost Ministarstva obrane, te uz Hrvatsku vojsku postaje sastavni dio Oružanih snaga. ${ }^{36}$ Dana 3. studenoga 1991. godine jedinice ZNG-a formalno su preimenovane u Hrvatsku vojsku. Istovremeno s izdvajanjem ZNG-a, za poslove vezane uz borbu protiv svih oblika terorističkog djelovanja, u MUP-a se osnivaju specijalne jedinice. ${ }^{37}$

\section{DJELOKRUG POSLOVA MUP-A U RAZDOBLJU 1990. - 1992.}

U razdoblju demokratske tranzicije, unutarnji poslovi kao resor državne uprave izravno su se nastavljali na upravu SR Hrvatske (Pusić, 1997: 185). Sustav republičke državne uprave bio je definiran Zakonom o upravi. ${ }^{38}$ Izmjenama postojeće zakonske regulative, MUP je dobio nove, proširene nadležnosti i djelokrug poslova koji su, pod unutarnje poslove, objedinjavali poslove zaštite državne sigurnosti, klasične policijske (redarstvene) poslove te obrambeno-redarstveno poslove.

\subsection{Djelokrug poslova Ministarstva}

Kako bi se situacija u području javne uprave uskladila s izvršenim demokratskim promjenama, u listopadu 1990. godine donosi se Zakon o ustrojstvu republičke uprave (dalje u tekstu: ZURU). ${ }^{39}$ Djelokrug poslova tada novoustrojenog MUP-a, sukladno ZURU-u, obuhvaćao je obavljanje upravnih i drugih stručnih poslova koji se odnose na: ,zaštitu ustavom utvrđenog poretka i poslove u oblasti javne sigurnosti koji se odnose na zaštitu života i osobnu sigurnost ljudi; sprječavanje

35 Na stadionu NK Zagreb 28. svibnja 1991. godine održana je prva smotra postrojbi ZNG-a i ostalih redarstvenih postrojbi MUP-a. Danas se taj dan slavi kao Dan oružanih snaga Republike Hrvatske i Dan Hrvatske kopnene vojske.

36 „Oružane snage čine jedinstvenu cjelinu i sastoje se od Hrvatske vojske $i$ Zbora narodne garde“. Čl. 38. Zakona o obrani, Narodne novine br. 49/1991, 53/1991 i 73/1991.

37 Usp. čl. 24. st. 1. Zakona o unutarnjim poslovima.

38 Narodne novine br. 16/1978, 50/1978, 29/1985, 48/1985, 41/1990, 47/1990. Zakon je prestao važiti 21. kolovoza 1993. stupanjem na snagu Zakona o sustavu državne uprave, Narodne novine br.75/1993.

39 Narodne novine br. 41/1990. ZURU je u naredne dvije godine više puta mijenjan i dopunjavan. V. Narodne novine br. 59/1990, 53A/1991, 61/1991, 73/1991, 22/1992, 34/1992. 
$i$ otkrivanje krivičnih djela; pronalaženje $i$ hvatanje počinilaca krivičnih djela $i$ njihovo privođenje nadležnim organima; održavanje javnog reda $i$ mira $i$ zaštita određenih ličnosti i objekata; obavljanje kriminalističko-tehničkih poslova; kontrolu i regulaciju prometa na cestama; kontrolu prelaska preko državne granice i kretanje $i$ boravak u graničnom pojasu, kretanje $i$ boravak stranaca; putnice za prelazak preko državne granice; održavanje javnih skupova; nabavu, držanje i nošenje oružja i municije; eksplozivne tvari; pružanje neophodne pomoći radi otklanjanja posljedica u slučaju opće opasnosti prouzrokovane elementarnim nepogodama $i$ epidemijama; poslove protupožarne inspekcije, obavljanje i drugih poslova koji su mu stavljeni u nadležnost, kao i poslova koji se odnose na: državljanstvo; osobne karte; prijavljivanje prebivališta i boravišta građana; vođenje evidencije $i$ statistike iz oblasti unutarnjih poslova; sistem informiranja u oblasti unutarnjih poslova; obrazovanje i usavršavanje radnika unutarnjih poslova" (čl. 19. ZURU-a). Uslijed potrebe iznalaženja adekvatnih rješenja za sve intenzivnije ugroze javne sigurnosti, postojeći je djelokrug unutarnjih poslova proširen donošenjem novele Zakona o unutarnjim poslovima u travnju 1991. godine (Narodne novine 19/1991). Temeljem generalne klauzule o nadležnosti, MUP je zajedno s drugim nadležnim tijelima bio dužan štititi pravni poredak i Ustavom utvrđeno državno ustrojstvo te nepovredivost državnog teritorija i braniti teritorijalnu cjelovitost Republike Hrvatske (čl. 3.). Pri tome je MUP obavljao poslove iz svog djelokruga samostalno, na temelju i u okviru ustava, zakona i drugih propisa, a u skladu s utvrđenom politikom Sabora Republike Hrvatske (čl. 4.). S obzirom na dualni (savezno-republički) sustav propisivanja poslova iz područja unutarnjih poslova u bivšoj državi, velika područja nadležnosti unutarnjih poslova bila su propisana saveznim zakonima. Radi potrebe zadržavanja kontinuiteta, ali i mogućnosti nesmetane primjene u novonastalim okolnostima, neposredno nakon proglašenja samostalnosti, 26. lipnja 1991. godine, donosi se Zakon o preuzimanju saveznih zakona iz oblasti unutarnjih poslova. ${ }^{40}$ Temeljem navedenog Zakona, u hrvatski je pravni sustav preuzet čitav niz zakona koji su vrijedili za područje SFRJ i počeli su se primjenjivati u Republici Hrvatskoj kao republički zakoni. Radilo se o sljedećim zakonima:

1. Zakon o osnovama sistema državne sigurnosti, ${ }^{41}$

2. Zakon o prelaženju državne granice i kretanju u graničnom pojasu, ${ }^{42}$

3. Zakon o kretanju i boravku stranaca, ${ }^{43}$

4. Zakon o osnovama sigurnosti prometa na cestama, ${ }^{44}$

5. Zakon o prometu eksplozivnih tvari, ${ }^{45}$

40 Narodne novine br. 51A/1991 od 8. listopada 1991. Usp. zapisnik 12. sjednice Sabora RH od 26. lipnja 1991., dostupno na www.sabor.hr/fgs.axd?id=43970 (10. ožujka 2016.).

41 Službeni list SFRJ br. 15/1984 i 42/1990.

42 Službeni list SFRJ br. 34/1979, 56/1980 i 53/1985, osim odredaba čl. 6., čl. 7., čl. 20. st. 1., čl. 30., čl. 34. st. 4., čl. 46., čl. 47. st. 2., čl. 48., čl. 49., čl. 50., čl. 51., čl. 57., čl. 67., čl. 68. i čl. 69.

43 Službeni list SFRJ, br. 56/1980, 53/1985, 30/1989 i 26/1990, odredbe od čl. 67. do čl. 75.

44 Službeni list SFRJ br. 50/1988, 80/1989, 29/1990 i 11/1991.

45 Službeni list SFRJ br. 30/1985. 


\section{Zakon o prijevozu opasnih tvari. ${ }^{46}$}

Pored navedenih zakona, bili su preuzeti i savezni propisi doneseni za izvršenje nabrojanih zakona te su se također trebali primjenjivati u Republici Hrvatskoj kao republički propisi, ako su bili u suglasnosti s Ustavom Republike Hrvatske i predmetnim zakonom. Proglašavajući samostalnost Republike Hrvatske 8. listopada 1991. godine, Hrvatski Sabor je usvojio i čitavi niz Zakona iz područja nadležnosti MUP-a. Možemo izdvojiti Zakon o hrvatskom državljanstvu, Zakon o prebivalištu i boravištu građana, Zakon o putnim ispravama hrvatskih državljana, Zakon o osobnoj iskaznici i Zakon o kretanju i boravku stranaca. ${ }^{47}$

\subsection{Djelokrug poslova redarstvenih službi}

\subsubsection{Poslovi zaštite Ustavom utvrđenog poretka}

Koji su poslovi u djelokrugu SZUP-a, nije precizirano na način kako je to učinjeno s ostale dvije redarstvene službe, sistemom imenovanja i nabrajanja poslova, već se neodređeno upućuje da su to „poslovi zaštite Ustavom utvrđenog poretka". Ovakva neodređena i općenita formulacija proizlazi iz karaktera i naravi obavještajne „tajne službe“, što je SZUP u svojoj suštini bio. Slična metoda koristila se i kod određivanja ovlasti službe, pa je tako SZUP bio ovlašten prikupljati podatke i obavijesti te poduzimati druge potrebne mjere i obavljati radnje radi otkrivanja i sprečavanja djelatnosti usmjerenih na podrivanje ili rušenje Ustavom utvrđenog poretka i ugrožavanja sigurnosti zemlje. ${ }^{48}$ Ako bi se uspoređivale djelatnosti i ovlasti, odnosno načini rada sa službom prednikom SZUP-a, onda je uočljiva sličnost. Međutim, $\mathrm{s}$ jednom bitnom razlikom koja se odnosila na odmak od dotadašnje komunističke paradigme, prvenstveno „unutarnjih i vanjskih neprijatelja režima““. ${ }^{49}$

\subsubsection{Poslovi policije}

Policija je kao redarstvena služba u djelokrugu poslova imala: zaštitu života i osobnu sigurnost ljudi, zaštitu imovine, sprečavanje i otkrivanje kaznenih djela, pronalaženje i hvatanje učinioca kaznenih djela i njihovo privođenje nadležnim organima, održavanje javnog reda i mira, obavljanje kriminalističko-tehničkih

46 Službeni list SFRJ br. 27/1990.

47 Cjeloviti popis odluka i ukaza o proglašenju zakona v. u Narodnim novinama br. 53/1991. Marčetić i Musa (2013: 730) navode kako su, nakon pada socijalizma i osamostaljivanja Hrvatske, Zakon o upravi te mnogi drugi zakoni iz bivše Jugoslavije preuzeti u novi pravni sustav i usklađeni s Ustavom RH, ali uglavnom u terminološkom i formalnom smislu.

48 Čl. 13. Zakona o unutarnjim poslovima.

49 Žunec i Domišljanović (200: 57) navode kako je „Služba u cjelini prihvatila promjene i bila funkcionalna u mirnom prijenosu vlasti “. Primjerice, autori ističu ulogu „Službe“ u vrijeme održavanja Prvog općeg sabora HDZ-a 24. - 25. veljače 1990. godine kada su obustavljene mjere prema „političkoj emigraciji“" pa je u zemlju slobodno doputovala velika skupina emigranata, odnosno bilo je obustavljeno poduzimanje mjera prema kategoriji ,unutarnji neprijatelji“. 
poslova, sigurnost i kontrolu te regulaciju prometa na cestama, kontrolu prelaska preko državne granice i kretanje i boravak u graničnom pojasu, kretanje i boravak stranaca, putovnice za prelazak preko državne granice i kretanje i boravak u graničnom pojasu, javne skupove, nabavljanje, držanje i nošenje oružja i streljiva, eksplozivne tvari, pružanje neophodne pomoći radi otklanjanja posljedica u slučaju opće opasnosti prouzročene elementarnim nepogodama i epidemijama, inspekciju u oblasti zaštite od požara i tehničkih pregleda vozila, osobne karte, vozačke isprave, registraciju vozila, prijavljivanje prebivališta i boravišta građana, državljanstvo. ${ }^{50}$ Pored navedenih, pobrojanih poslova, policiji je bila propisana obveza obavljanja i ostalih unutarnjih poslova za čije obavljanje nije bila predviđena nadležnost druge redarstvene službe, pri čemu se nigdje ne precizira koji bi to drugi poslovi stvarno i bili. ${ }^{51}$ No suštinska posebnost ovog razdoblja koju treba posebno apostrofirati jest da je policija, koristeći limitirane materijalne i ljudske resurse, pored permanentnog ispunjavanja funkcije društvene regulacije (o tome v. Pusić, 1985: 262-266), morala ponijeti i teret suzbijanja pobune i obrane države (Gregurić, 1998: 448).

\subsubsection{Obrambeno-redarstvene dužnosti ZNG-a}

Djelokrug poslova ZNG-a odnosio se na: zaštitu državne granice Republike Hrvatske te zaštitu nepovredivosti državnog teritorija, narušavanje javnog reda i mira u većem opsegu, zaštitu od terorističkog i drugog nasilnog djelovanja odnosno oružane pobune, zaštitu zračnih luka i zračnog prometa, zaštitu obale i mora, pružanje pomoći radi otklanjanja posljedica u slučaju opće opasnosti prouzročene elementarnim nepogodama i drugih akcidenata, zaštitu određenih osoba, objekata i prostora, te na druge poslove utvrđene zakonom. ${ }^{52}$ Ustrojstvene jedinice ZNG-a u obavljanju poslova iz svog djelokruga mogle su djelovati samostalno i zajedno s drugim redarstvenim službama Ministarstva i službama Ministarstva obrane, pri čemu su imale zakonsku obvezu pružati pomoć državnim tijelima u slučajevima određenim zakonom. ${ }^{53}$ Prelaskom ZNG-a kao ustrojstvene organizacije $u$ Ministarstvo obrane, većina poslova ZNG-a prestaje biti u nadležnosti MUP-a.

50 Čl. 1. st. 2. Zakona o unutarnjim poslovima.

51 Usp. čl. 20. Zakona o unutarnjim poslovima. O problematici neodređenog propisivanja nadležnih poslova unutar sustava unutarnjih poslova v. Pusić, Ivanišević, Pavić i Ramljak, 1988: 178. usp. i Tomašević, 1989: 19-20. Ivanda, 1995. U razmatranom, tranzicijskom razdoblju uočljiva je konfuzna situacija utvrđivanja važećih pravnih akata. Stoga je nemoguće preciznije odrediti koji su to dodatni poslovi bili u nadležnosti redarstvenih službi. Međutim, također treba konstatirati kako neodređenost obima policijskih poslova nije bila pojava trenutačnog karaktera, nego se takva situacija provlači sve do današnjih dana. Tako Staničić konstatira kako je policija dužna, uz propisane policijske poslove, i sukladno svojim mogućnostima, poduzeti i hitne mjere nužne za otklanjanje izravne opasnosti za ljude i imovinu, ako je očito da te mjere ne može pravodobno poduzeti nadležno tijelo, a s obzirom na to da se radi o hitnim mjerama, čekanje da postupi nadležno tijelo proizvelo bi ugrozu za ljude $\mathrm{i}$ imovinu. Iz toga je vidljivo ,... kako su policijski poslovi u osnovi neograničeni, budući da je policiji stavljeno u nadležnost obavljanje svih radnji iz nadležnosti drugih tijela, bilo državne uprave, bilo lokalne i područne (regionalne) samouprave“. Staničić, 2015: 62. O pravnom djelokrugu u obavljanju unutarnjih poslova v. Franulović, 2016.

52 Čl. 1. st. 3. Zakona o unutarnjim poslovima.

53 čl. 26. st. 2. Zakona o unutarnjim poslovima. 
Izmjenama i dopunama Zakona o unutarnjim poslovima koje su stupile na snagu 31. prosinca 1991. godine, ${ }^{54}$ od dotadašnjih poslova ZNG-a u kontinuiranoj nadležnosti MUP-a ostaju poslovi zaštite državne granice Republike Hrvatske, zaštite određenih osoba, objekata i prostora od posebnog interesa. ${ }^{55}$ Istim izmjenama, u čl. 3. propisuje se da poslove vezane za borbu protiv svih oblika terorističkog djelovanja obavljaju specijalne jedinice. Time je kraj kalendarske 1991. godine predstavljao i prestanak postojanja redarstvene službe ZNG-a s nadležnostima i poslovima koji su imali obilježja prvenstveno vojnih, a tek potom „klasičnih“ policijskih poslova. U narednom razdoblju do kraja Domovinskog rata, redarstvene se službe dodatno organizacijski diferenciraju na: policiju, kriminalističku policiju i specijalnu policiju. ${ }^{56}$ Međutim, ustrojstvene jedinice vojno-policijskog ustroja i područja nadležnosti, slične ZNG-u, u Republici Hrvatskoj više se nisu osnivale.

\section{ZAKLJUČAK}

Proces osamostaljivanja Republike Hrvatske odvijao se u prilikama koje su imale obilježja faktičnog izvanrednog stanja već od kolovoza 1990. godine kad je započela tzv. balvan-revolucija. Izvanredne okolnosti uvelike su determinirale formiranje pravnih i organizacijskih pretpostavki za stvaranje cjelovite državne uprave. U tom procesu, jedan od prioriteta bilo je ustrojavanje redarstveno-vojne strukture sposobne za efikasno preuzimanje svih obveza sigurnosnog sustava buduće samostalne države. Pokretanje tečaja Prvi hrvatski redarstvenik, u ljeto 1990. godine, označilo je početak stvaranja novih redarstvenih jedinica kao okosnice unutarnjih poslova. Značajno jačanje sigurnosnog sustava ostvareno je u proljeće 1991. godine ustrojavanjem novih redarstvenih službi. Pored SZUP-a i policije, najveću ustrojstvenu novinu predstavljala je redarstvena služba ZNG, osnovana s primarnim ciljem zaštite od oružane pobune i nepovredivosti državnog teritorija. Imajući u vidu sve što se poslije događalo, može se ocijeniti da je osnivanje ZNG-a bila strateški ispravna i dalekosežno učinkovita odluka jer su time postavljeni temelji osnivanja i razvoja Hrvatske vojske. Bez formiranja profesionalnih i pričuvnih postrojbi ZNG-a i njihova operativnog angažmana u sinergiji s drugim redarstvenim službama, teško je i zamisliti da bi se Hrvatska uspješno obranila. Usporedno s osnivanjem novih redarstvenih službi, mijenjao se i teritorijalni organizacijski ustroj. Uvođenjem centraliziranog sustava početkom 1990. godine, osnivaju se pored postojećih policijskih postaja i nove ustrojstvene cjeline policijske uprave (18) te policijske ispostave (111). Formiranje višestupanjskih hijerarhijski podređenih ustrojstvenih jedinica omogućilo je učinkovitije upravljanje sustavom. No, također je u bitnome povećan broj upravnih organizacijskih jedinica (vertikalne diferencijacije) i neposrednih izvršitelja što će postati konstanta u narednom razdoblju. Osnivanje policijskih uprava, kao druge razine teritorijalnog ustroja,

54 Narodne novine br. 73/1991.

55 Isto, u čl. 1. dodana je t. 3. kojom su obuhvaćeni navedeni poslovi.

56 Usp. Zakon o izmjenama i dopunama zakona o unutarnjim poslovima, Narodne novine br. 76/1994. 
može se smatrati i pretečom kasnije upravno-teritorijalne podjele države na županije te povezivanje teritorijalnog ustroja s teritorijalnim nadležnostima novoformiranih policijskih uprava 1993. godine. Proširenje djelokruga MUP-a nastupilo je zbog više razloga. Prije svega, trebalo je preuzeti one unutarnje poslove koji su do tada bili u nadležnosti saveznih tijela vlasti kao što su zaštita državne granice, posebna zaštita objekata i osoba, protuterorističke aktivnosti i dr. Zatim, valjalo je ustrojiti i operativno osamostaliti od nadležnosti saveznih tijela vlasti, službu za zaštitu ustavnog poretka, dotadašnju politički indoktriniranu policijsku „tajnu službu“. I ono što je u tadašnjem vremenu bilo najurgentnije - valjalo je pravno propisati mogućnosti da redarstvene službe obavljaju poslove neposredno vezane za suzbijanje pobune i ratne agresije, odnosno obrambene poslove. Potpisivanjem „Sarajevskog primirja“, međunarodnim priznanjem a potom i raspoređivanjem mirovne misije UNPROFOR, ostvareni su uvjeti da sve organizacijske sastavnice MUP-a, iz ratnog rasporeda i poslova primarno usmjerenih na obrani domovine, naprave pomak prema „redovnim“ civilno-redarstvenim djelatnostima, zaštiti ustavnog poretka te održavanju povoljnog stanja javne sigurnosti i javnog reda i mira. No, ne u potpunosti jer će, pored Hrvatske vojske, i pripadnici MUP-a biti do kraja Domovinskog rata aktivno uključeni na zadacima obrane i oslobađanja zemlje.

\section{LITERATURA}

1. Anić, V. (1994.). Rječnik hrvatskog jezika. Zagreb: Novi Liber.

2. Bačić, A. (1997.). „Odredbe o „stanju nužnosti“ u Ustavu Republike Hrvatske iz 1990. godine“, Zbornik radova Pravnog fakulteta u Splitu, 34 (1-2), 39-57.

3. Barić, N. (2005.). Srpska pobuna u Hrvatskoj 1990. - 1995. Zagreb: Golden marketing-Tehnička knjiga.

4. Barić-Punda, V. (2001.). „Hrvatska, od samostalnosti i neovisnosti do međunarodnog priznanja“, Zbornik radova Pravnog fakulteta u Splitu, 38, 4 (64), 339-349.

5. Beuc, I. (1985.). Povijest institucija državne vlasti Kraljevine Hrvatske, Slavonije i Dalmacije, Zagreb: Pravni fakultet.

6. Borković, I. (1991.). Upravno pravo, Zagreb: Informator.

7. Borković, I. (2002.). Upravno pravo, Zagreb: Narodne novine.

8. Čepulo, D. (2012.). Hrvatska pravna povijest u europskom kontekstu od srednjeg vijeka do suvremenog doba. Zagreb: Pravni fakultet Sveučilišta u Zagrebu.

9. Fabijanić-Gagro, S. i Vukas, B. (2008.). „Pravna priroda i politička pozadina oružanih sukoba u Hrvatskoj i Bosni i Hercegovini“", Zbornik Pravnog fakulteta u Zagrebu 58(5), 1159-2000.

10. Filipović, V. (2015.). Ispod plavih šljemova: Motivi država za sudjelovanjem u misiji UNPROFOR 1992. - 1995., Zagreb: Olejada.

11. Franulović, D. (2016.). „Upravno područje unutarnjih poslova u Republici Hrvatskoj“, Zagrebačka pravna revija, 5 (1), 61-84. 
12. Franulović, D. i Tadić, J. (2011.). „Postupanje policije prema uredbama iz nužde Predsjednika Republike Hrvatske iz 1991. - 1992.“. Policija i sigurnost, br. 4, 530-535.

13. Gardašević, Đ. (2011.). „Ustav Republike Hrvatske i ‘Stanje izuzetka’“, u: Bačić, A. (ur.), Dvadeseta obljetnica Ustava Republike Hrvatske: Okrugli stol održan 16. prosinca 2010. u palači HAZU u Zagrebu, str. 413-430.

14. Gregurić, F. (1998.). Vlada demokratskog jedinstva Hrvatske: 1991. - 1992., Zagreb: Naklada Zadro.

15. Ivanda, S. (1995.). Pregled policijskog prava, Zagreb: MUP RH.

16. Ivanda, S. (2004.). Policijsko upravno pravo, Zagreb: Narodne novine.

17. Jakešević, R. (2012.). Hrvatska i mirovne misije ujedinjenih nacija. Fakultet političkih znanosti Sveučilišta u Zagrebu, Politička kultura.

18. Josipović, I. (1995.). „Uredbe za slučaj izvanredne situacije i njihov utjecaj na temeljna ljudska prava u kaznenom postupku“. Hrvatski ljetopis za kazneno pravo i praksu, br. 2, str. 278-291.

19. Kapetanović, R. M. (1997.). Kronologija zbivanja u Republici Hrvatskoj 1989. 1995. Zagreb: Informator.

20. Kasapović, M. (1996.). „Demokratska tranzicija i političke institucije u Hrvatskoj“, Politička misao, vol. 33, br. 2-3, 84-99.

21. Koprić, I. (2006.). „Razvoj lokalne samouprave u Hrvatskoj - problemi i vrijednosne orijentacije“, u: Koprić, I. (ur.), Javna uprava - nastavni materijali, Društveno veleučilište u Zagrebu i Pravni fakultet u Zagrebu.

22. Koprić, I. (2006.). „Razvoj javne uprave u Hrvatskoj: okviri, iskustva i perspektive“, u: Koprić, I. (ur.), Javna uprava - nastavni materijali, Društveno veleučilište u Zagrebu i Pravni fakultet u Zagrebu.

23. Koprić, I. (2010.). „Stanje lokalne samouprave u Hrvatskoj“. Hrvatska javna uprava 10 (3): 665-681.

24. Koprić, I. (2011.). „Contemporary Croatian Public Administration on the Reform Waves“. Godišnjak Akademije pravnih znanosti Hrvatske, II (1). Doj: 351. (4EU:497.5). preuzeto s https://hrcak.srce.hr/79893 (2. veljače 2018.).

25. Koprić, I. (2015). Položaj policijskih službenika u Republici Hrvatskoj: rezultati znanstvenog istraživanja i preporuke za poboljšanje, Zagreb: Sindikat policije Hrvatske u partnerstvu s Institutom za javnu upravu.

26. Koprić, I., Marčetić, G., Musa, A., Đulabić, V. i Lalić-Novak, G. (2014.). Upravna znanost - javna uprava u suvremenom europskom kontekstu. Zagreb: Pravni fakultet Sveučilišta u Zagrebu i Studijski centar za javnu upravu i javne financije.

27. Kosnica, I. (2011.). „Uredbe iz nužde predsjednika Republike Hrvatske iz 1991.1992.“, Zbornik Pravnog fakulteta u Zagrebu, br. 61(1), 149-179. 
28. Marčetić, G. (2006.). „Uloga javnih službenika u tranziciji“, u: Koprić, I. (ur.), Javna uprava - nastavni materijali. Zagreb: Društveno veleučilište i Pravni fakultet u Zagrebu.

29. Marčetić, G. i Musa, A. (2013.). „Europeizacija službeničkog prava: usklađivanje hrvatskog zakonodavstva s europskim standardima“, Zbornik radova Pravnog fakulteta $u$ Splitu, god. 50, br. 3. 725-756.

30. Marijan, D. (2006.). „Hrvatsko ratište 1990. - 1995.“, u: Radelić, Z., Marijan, D., Barić, N., Bing, A. i Živić, D., Stvaranje hrvatske države i Domovinski rat, Zagreb: Školska knjiga.

31. Mikulan, K. (2003.). Povijest policije u Hrvatskoj, Varaždin: Tonimir.

32. Manolić, J. (2015.). Politika i domovina, Zagreb: Golden marketing - Tehnička knjiga.

33. Nazor, A. (2011.). Hrvatska policija u Domovinskom ratu. Zagreb: MUP RH.

34. Nobilo, M. (2000.). Hrvatski feniks: diplomatski procesi iza zatvorenih vrata: 1990.-1997. Zagreb: Nakladni zavod Globus.

35. Omejec, J. (1996.). „Ograničavanja sloboda i prava čovjeka i građanina u izvanrednim stanjima“, Društvena istraživanja: Časopis za opća društvena pitanja, vol. 5, br. 2(22), 365-369.

36. Pusić, E. (1985.). Upravni sistemi I. Zagreb: Grafički zavod Hrvatske.

37. Pusić, E. (1997.). Hrvatska središnja državna uprava i usporedni upravni sistemi, Zagreb: Školska knjiga.

38. Pusić, E. (2002.). Nauka o upravi, Zagreb: Školska knjiga.

39. Pusić, E., Ivanišević, S., Pavić, Ž. i Ramljak, M. (1988.). Upravni sistemi, 4. izdanje, Zagreb: Narodne novine.

40. Pušeljić, M., Magušić, F. i Nađ, I. (2008.). Organizacija i funkcioniranje policije, Zagreb: MUP RH.

41. Runtić, D. (2003.). Prvi hrvatski redarstvenik, Zagreb: Udruga Prvi hrvatski redarstvenik.

42. Rudolf, D. (1999.). Rat koji nismo htjeli, Hrvatska 1991. Zagreb: Nakladni zavod Globus.

43. Rudolf, D. (2017.). Stvaranje Hrvatske države 1991. - Ministarska sjećanja, Zagreb: Školska knjiga.

44. Savić, D. (2012.). „Položaj policije u sustavu nacionalne sigurnosti“, Političke analize, Fakultet političkih znanosti Zagreb, vol. 3., br. 12, 6-11.

45. Silber, L. i Little, A. (1996.). Smrt Jugoslavije, Opatija: Otokar Keršovani.

46. Smerdel, B. (2013.). Ustavno uređenje europske Hrvatske, Zagreb: Narodne novine.

47. Staničić, F. (2015.). Policijsko upravno pravo, Zagreb: Narodne novine.

48. Špregelj, M. (2001.). Sjećanje vojnika, Zagreb: Znanje d.d. 
49. Šterc, S. i Pokos, N. (1993.). „Demografski uzroci i posljedice rata protiv Hrvatske“, Zagreb, Društvena istraživanja, Časopis za opća društvena pitanja, br. 2-3, 305-333.

50. Tatalović, S. (2006.). Nacionalna i međunarodna sigurnost, Zagreb: Politička kultura.

51. Tomašević, P. (1989.). Upravno pravo - posebni dio unutrašnji poslovi, Zagreb, RSUP RH.

52. Vukas, B. (2002.). „Državnopravni aspekti konstituiranja Hrvatske države 1989.1992.“, Zbornik Pravnog fakulteta Sveučilišta u Rijeci, vol. 23, br. 2, 645-681.

53. Vukas, B. i Fabijanić-Gagro, S. (2011.). „Pravnopovijesne i međunarodnopravne odrednice (dez)integracijskih procesa država sljednica SFRJ“, Zbornik radova Pravnog fakulteta u Splitu, vol. 48, br. 3, 577-612.

54. Zmijarević, N. (2007.). Policija u Hrvatskoj 1941-2001. Zagreb, MUP RH.

55. Žunec, O. i Domišljanović, D. (2000.). Obavještajno-sigurnosne službe Republike Hrvatske, Zagreb: Naklada Jesenski i Turk.

56. Walka, A. (1923.). Priručnik za redarstvenu službu, Zagreb, vlastita naklada.

\section{SUMMARY}

The independence process of the Republic of Croatia required the formation of all branches of the administrative system inherent in an independent state. Due to the state of emergency naimly the riots and war aggression, formation of an independent and fully operational administrative system of the Internal affairs was of vital importance in terms of maintenance of internal security. The purpose of this paper is to explore the organizationls specifities and the scope of work of the Ministry of the Interior from the beginning of 1990 until 1992. In order to achive this gol, the paper gives the historical overview of the political transition, with an emphasis on events which had essentially determined the direction and dynamics of the development process within the Internal affains branch. Forms of organization will be explored and analyzed at all levels of vertical differentiation, as well as the scope of competence of the Ministry's organizational units. Special emphasis is placed on different police services.

Keywords: internal affairs, state of emergency, police services 